\title{
Lateral periodontal cyst with extremely rare clinical-radiographic presentation
}

\section{Cisto periodontal lateral com apresentação clínico-radiográfica extremamente rara}

\begin{abstract}
Purpose: The present article describes the clinical, radiographic and histological features of an extremely rare case of lateral periodontal cyst as well as the treatment and postoperative follow-up.

Case description: A 43-year-old male patient, mulatto, sought the Stomatology Clinic of the Caruaru Dental School (Brazil) with a complaint of increased volume on the right side of his face for approximately five years. The increase in volume was asymptomatic and facial asymmetry was the main reason he sought treatment. Based on the clinical and imaging exams as well as the lack of pulp vitality in tooth 13 , the presumed clinical diagnosis was inflammatory radicular cyst and the surgical plan was total cystic enucleation. Excisional biopsy was performed and sent for pathologic microscopic analysis, which revealed multiple cavities with hyalinization of the connective tissue below the epithelium and the presence of clear non-epithelial cells.

Conclusion: The case reported reveals that the extremely rare botryoid variant of lateral periodontal cyst exhibits multilocular presentation and excessive growth. Excisional biopsy was the treatment for this case and no sign of recurrence was observed over the nine-month follow-up period.
\end{abstract}

Key words: Odontogenic cysts; periodontal cyst; Oral Pathology

\section{Resumo}

Objetivo: $\bigcirc$ presente artigo descreve os aspectos clínicos, radiológicos e histopatológicos de um caso extremamente raro de cisto periodontal lateral, bem como o tratamento e acompanhamento pós-cirúrgico.

Descrição do caso: Um paciente masculino de 43 anos de idade, mulato, procurou a Clínica de Estomatologia da Faculdade de Odontologia de Caruaru (Brasil) queixando-se de grande aumento de volume no lado direito de seu rosto de aproximadamente cinco anos. Tal aumento de volume era assintomático e a assimetria facial foi o principal motivo pelo qual procurou o tratamento. Com base nos exames clínicos e radiográficos, bem como a falta de vitalidade pulpar no elemento 13, a hipótese diagnóstica foi de cisto radicular inflamatório e o plano cirúrgico envolveu a competa enucleação cística. A biópsia excisional foi realizada e enviada para análise histopatológica, a qual revelou múltiplas cavidades com hialinização do tecido conjuntivo abaixo do epitélio e presença de células não-epiteliais.

Conclusão: $O$ caso relatado revelou que a extremamente rara variação botrióide do cisto periodontal lateral possui aparência multilocular e crescimento excessivo. A biópsia excisional foi o tratamento para esse caso e nenhum sinal de recorrência foi observado durante o acompanhamento de nove meses.

Palavras-chave: Cistos odontogênicos; cisto periodontal; patologia bucal

\author{
Marconi Eduardo S Maciel-Santos a \\ Vinícius de Farias Pereira a \\ Pettely Thaíse de S Santos Palmeira a \\ Diego Moura Soares a \\ Danielle Lago Bruno de Faria a \\ Uoston Holder da Silva a
}

- ASCES College, Caruaru Dental School, Caruaru, PE, Brazil

\section{Correspondence:}

Marconi Eduardo Sousa Maciel Santos Av. Portugal, 584 - Bairro Universitário Caruaru, PE - Brazil 55016-400

E-mail:marconimaciel@gmail.com

Conflict of Interest Statement: The authors state that there are no financial and personal conflicts of interest that could have inappropriately influenced their work.

Copyright: (c) 2011 Maciel-Santos et al.; licensee EDIPUCRS. This is an Open Access article distributed under the terms of the Creative Commons AttributionNoncommercial-No Derivative Works 3.0 Unported License. 


\section{Introduction}

Lateral periodontal cyst (LPC) is an unusual cyst of odontogenic origin, most frequently found in the mandible between the roots of canines and premolars and corresponding to $0.7 \%$ to $1 \%$ of all cysts found in the jaw (1). This lesion develops in the alveolar bone alongside an erupted vital tooth. As pain and other clinical signs are rarely reported (asymptomatic), this non-keratinized and non-inflammatory developmental cyst is diagnosed during routine radiographs, in which it exhibits a radiolucent image less than one $\mathrm{cm}$ in diameter in most cases $(1,2)$. Regarding incidence, there is a clear predominance among males in the fifth and sixth decades of life (3).

LPC is related to an adjacent vital tooth in most cases and there is considerable difficulty in its identification following endodontic treatment due to the possibility of lesion caused by infection of a lateral root canal (4). The origin of LPC is not fully known, but three likely possibilities are reported: reduced enamel epithelium, remnants of dental lamina and cell rests of Malassez (5).

The features of a lateral periodontal cyst can be easily confused with a odontogenic keratocyst developing between roots or a more lateral radicular cyst. Thus, in addition to clinical and radiographic findings, histopathological analysis is essential for the diagnosis of the lesion (6). Histologically, LPC is characterized by a thin layer of non-keratinized epithelium and thick cell layer, which resembles reduced enamel epithelium. Inflammation is not one of its aspects and the walls consist of fibrous collagen tissue (4).

Regarding the differential diagnosis, botryoid odontogenic cyst (an uncommon lesion of the jaw bones) is considered a multilocular variant of lateral periodontal cyst due to its microscopic presentation. The distinction is due to the presence of multiple pathologic cavities, which give it a multicystic appearance (7). For unknown reasons, the recurrence rate of botryoid cyst ranges from 15 to $33 \%$ greater than that for LPC. ${ }^{2}$ Botryoid cysts are routinely treated with enucleation (1).

The present study describes the clinical, radiographic and histological features of an extremely rare case of lateral periodontal cyst as well as the treatment and postoperative follow-up.

\section{Description of the Case}

A 43-year-old male patient, mulatto, sought the Stomatology Clinic of the Caruaru Dental School (Brazil) with a complaint of increased volume on the right side of his face for approximately five years, having emerged with no apparent cause. The increase in volume was asymptomatic and facial asymmetry was the main reason he sought treatment.

The extra-oral exam revealed a considerable increase in volume on the entire right side of the face, involving the infra-orbital and zygomatic regions, with blurring of the respective nasal-labial and nasal-genial furrows (Fig. 1).
The examination of the oral cavity revealed poor dental and periodontal status, with a number of missing teeth, calculus build up, bleeding gums, gingival recession and advanced periodontitis. There was also an increased volume in the right vestibular region, extending from the area adjacent to tooth 13 to tooth 16 .

The imaging exams (panoramic radiography and conebeam volumetric tomography) revealed well-defined, unilocular, radiolucent areas circumscribed by a radiopaque halo extending through the aforementioned areas and adjacent to the apices of teeth 13 and 15 (Fig. 2). Due to the radiolucency, it was not possible to view the limits of the anterior wall or floor of the maxillary sinus.

Based on the clinical and imaging exams as well as the lack of pulp vitality in tooth 13 (cold pulp vitality test), the presumed clinical diagnosis was inflammatory radicular cyst and the surgical plan was total cystic enucleation and extraction of the damaged teeth involved.

Surgery occurred in a clinical setting with the patient conscious and under local anesthesia with blockers. A semi-technical aspirating injection was performed with a disposable 20-ml syringe and 25-G needle, which revealed a semi-solid content with citrine yellow coloration and cholesterol crystals. From these findings, a modified Neumann incision was employed, pulling back the mucoperiostal flap to reveal the edges of the cyst, which was delimited and had a well-defined capsule. Enucleation was performed with no serious complications. Tooth 13 and the remaining root from tooth 15 were also removed during the same operation. Following the enucleation, curettage and cleaning of the cavity, the surgical wound was closed with simple stitches along the incision lines (Fig. 3).

Excisional biopsy was the treatment for the lesion in question, which was sent for pathological analysis. The material consisted of a piece approximately $25 \mathrm{~mm}$ x $35 \mathrm{~mm}$ at its largest point. Microscopically, there was the presence of multiple cavities, with hyalinization of the connective tissue below the epithelium and the presence of clear nonepithelial cells (Fig. 4). The diagnosis was the botryoid variant of lateral periodontal cyst.

Postoperative control was rigorous for this case and follow up was initially carried out on a weekly basis. After seven days, the patient exhibited a significant reduction in facial volume and had no important complaints. The surgical wound was satisfactory, with no signs of complications that would justify the removal of the stitches. At 14 days, there was a significant reduction in swelling in the area and adequate healing for the time elapsed since the surgery and a new panoramic radiograph was solicited (Fig. 5).

Two months following the enucleation of the cyst, radiographic findings revealed areas of osteogenesis and the region was clinically satisfactory, as expected for this interval. This condition remained stable at the five-month and nine-month follow up evaluations, with no sign of recurrence or alteration in either the clinical or radiographic exams (Fig. 6). 


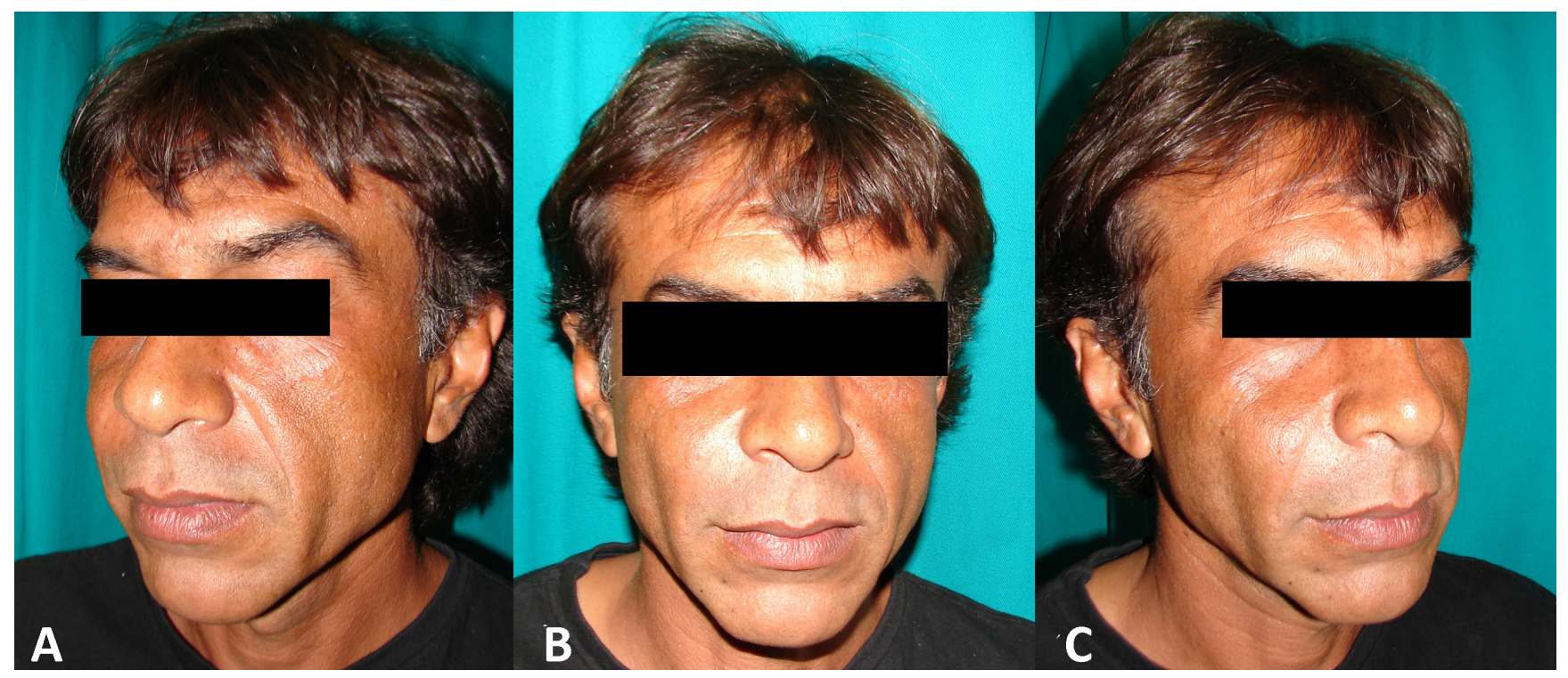

Fig. 1. Clinical aspect of patient in right oblique view (A), frontal view (B) and left oblique view (C).

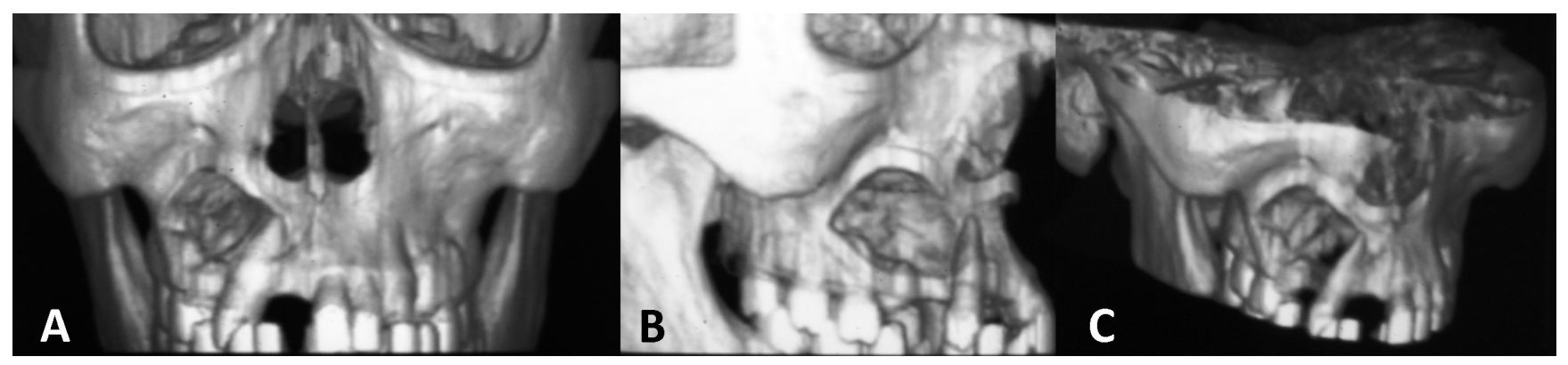

Fig. 2. Anterior view (A), lateral view (B) and anterosuperior view (C) of maxilla by computed tomography 3D reconstruction revealing cyst cavity.

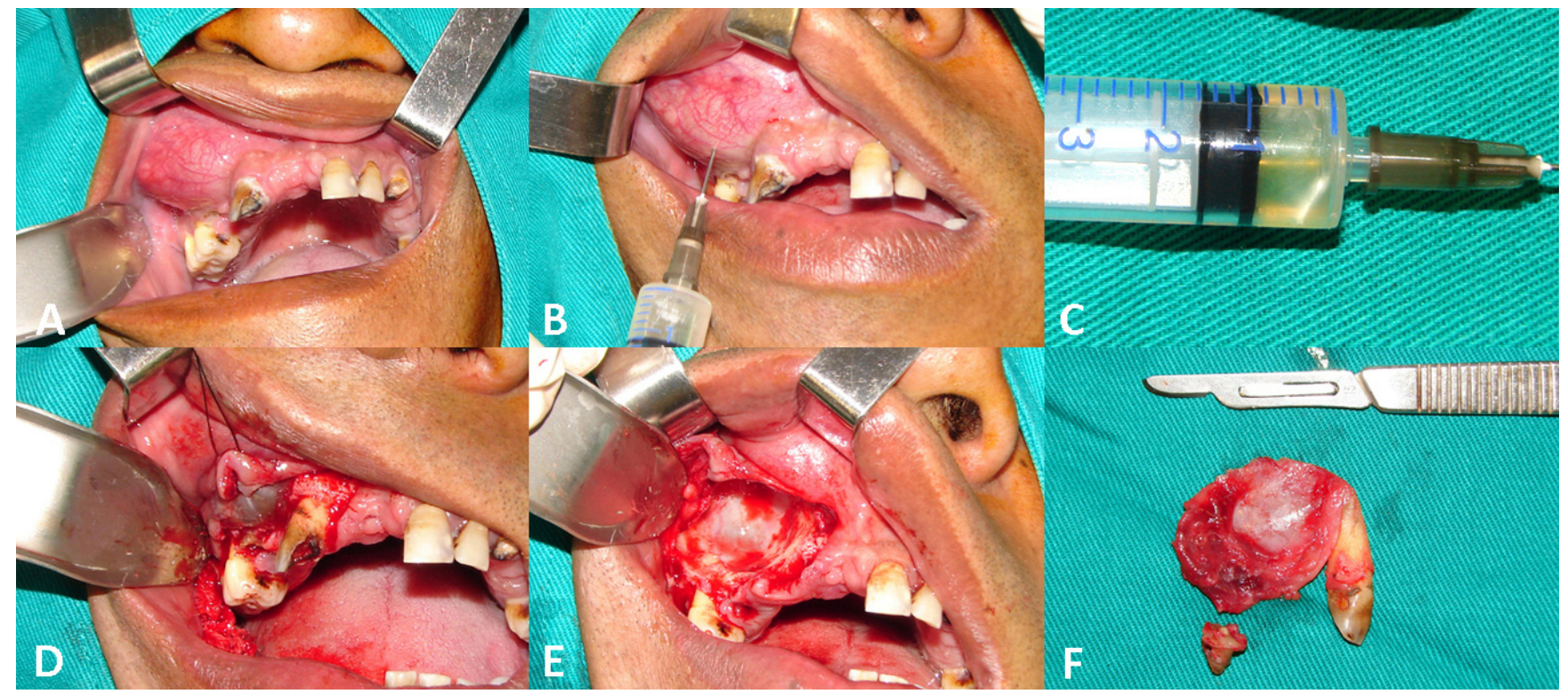

Fig. 3. Intraoral clinical aspect (A); Needle aspiration maneuver (B); Detection of cystic fluid (C); Incision and detachment of mucoperiosteal flap, showing cystic capsule to be enucleated (D); Cavity after removal of cyst (E); Surgical specimen adhered to tooth root \# 13 and root remnant of tooth \# 15 (F) 


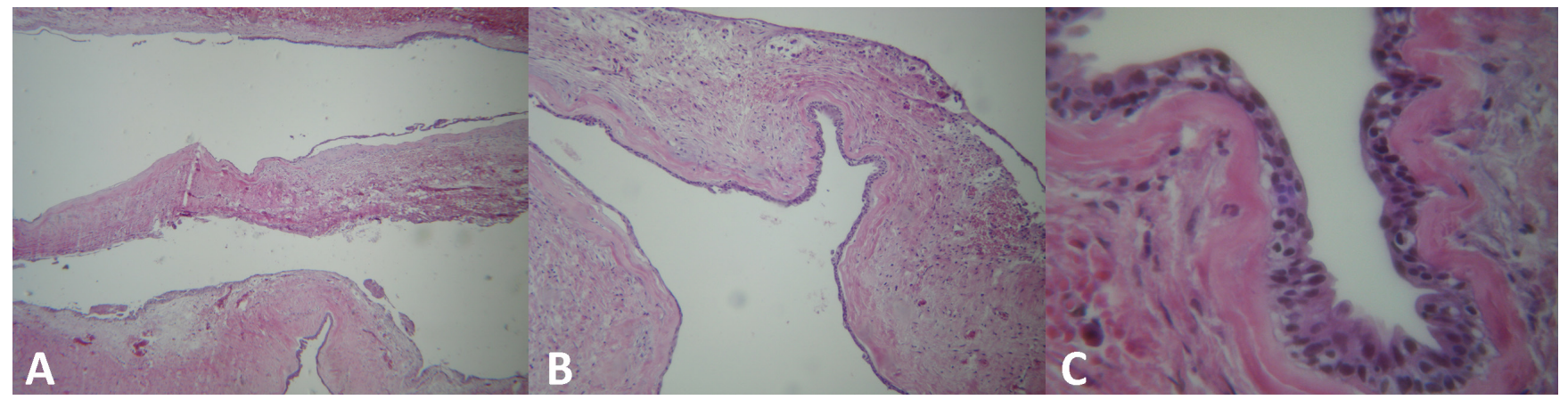

Fig. 4. Histological aspect of cyst at magnification of 40x (HE) (A), 100x (HE) (B) and 400x (HE) (C), revealing presence of multiple cavities, with hyalinization of tissue below epithelium.

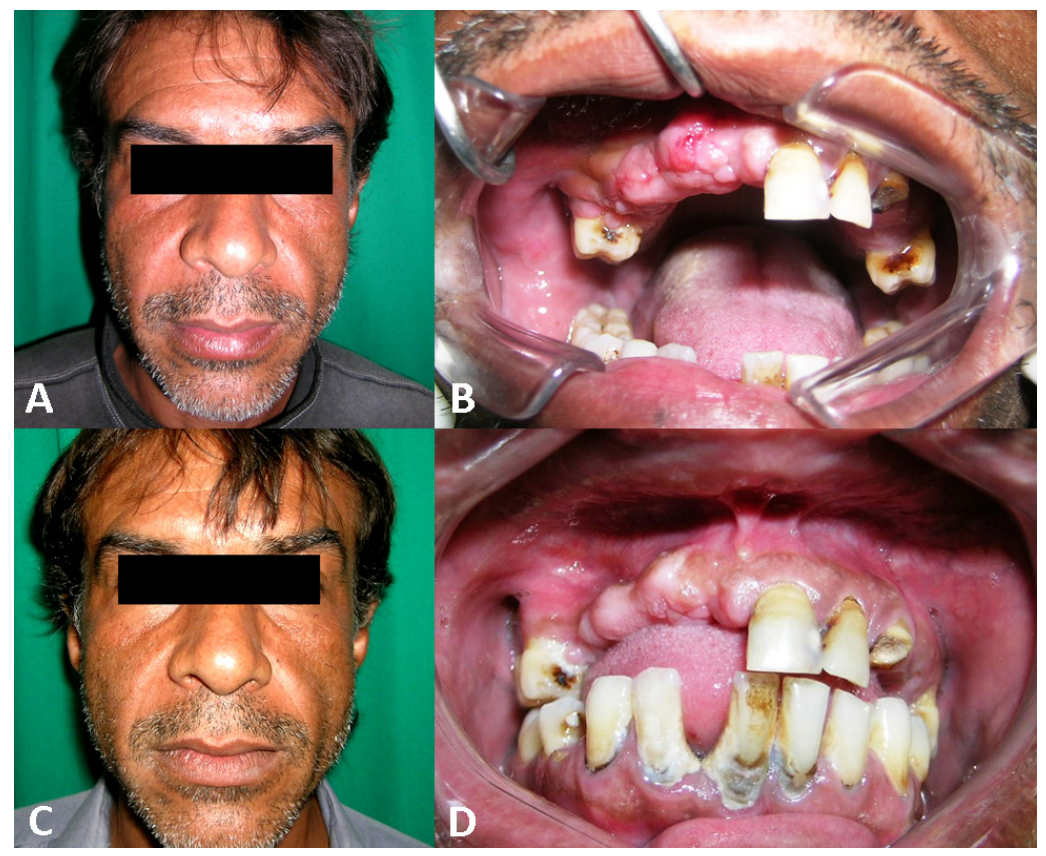

Fig. 5. Extraoral (A) and intraoral (B) clinical aspect at 7 days following removal of cyst; Extraoral (C) and intraoral (D) clinical aspect at 14 days following removal of cyst.

Fig. 6. Extraoral (A) and intraoral (B) clinical aspect at 5 months following removal of cyst; Extraoral (C) and intraoral (D) clinical aspect at 9 months following removal of cyst.

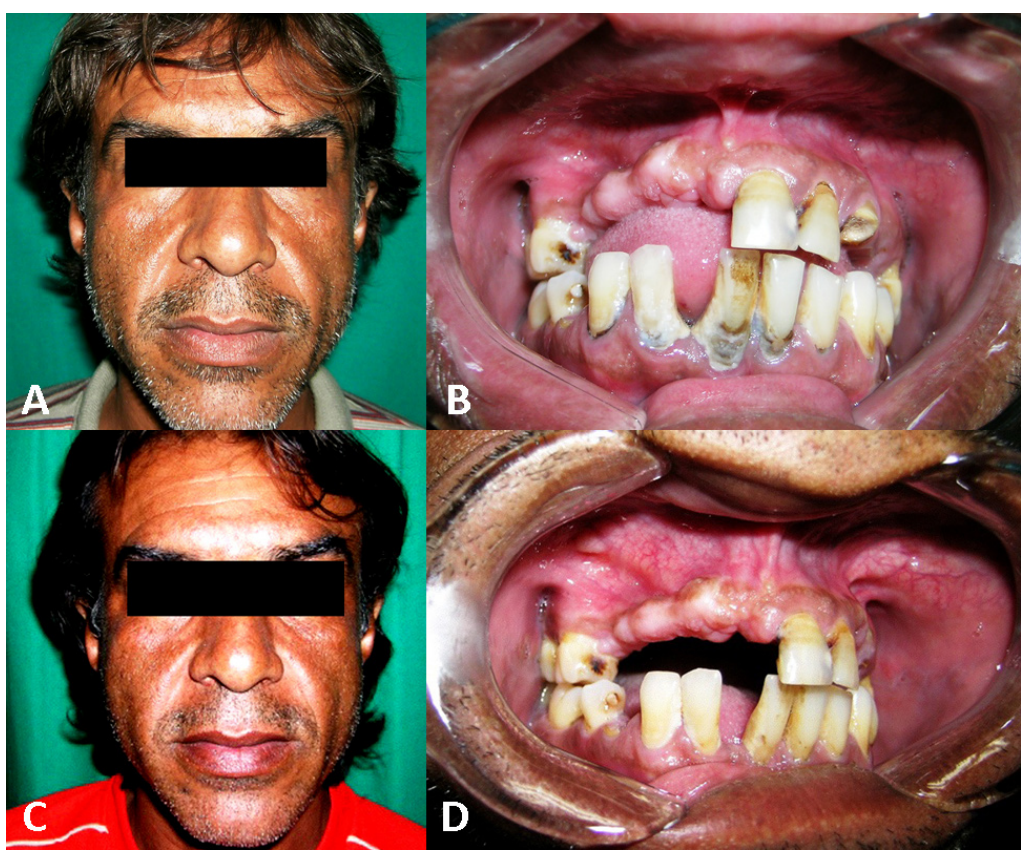




\section{Discussion}

Lateral periodontal cyst is a very uncommon lesion, corresponding to 0.8 to $1.5 \%$ of all maxillary cysts (3). When it develops along the root surface (as occurred in the case reported here), it can easily be confused with an odontogenic keratocyst or lateral radicular cyst (1). An important aspect that can provide the differential diagnosis between a radicular cyst and LPC is the fact that the former is characterized by necrosis of the affected tooth, whereas the tooth remains vital in the latter and no root canal treatment is required (3).

Huang et al. report a case in which a calcifying odontogenic cyst was radiographically diagnosed as LPC, revealing similarities between these conditions that can only be differentiated through careful clinical analysis and histological features (8). There have also been reports of lesions clinically diagnosed as periodontal lateral cysts, but which were found to be malignant lesions in the histological study (3).

While some authors claim that there is a clear male predominance, others report equal sex distribution $(3,5,9)$. LPC can have a polycystic appearance and, in such cases, is denominated a botryoid odontogenic cyst. This cyst is simply a multi-focal variant of LPC, which can be seen in radiographs as well as on both the microscopic and macroscopic levels (6). A botryoid cyst has a greater risk of recurrence. Two cases of recurrence are described in the literature, probably due to its polycystic nature $(1,10)$. LPC is asymptomatic, whereas most botryoid cysts may have symptoms, perhaps due to their larger size (2). In the case reported here, the rare botryoid variant was found, but its excessive growth had not caused any signs or symptoms except facial asymmetry.

The differential diagnosis requires the analysis of multiple aspects, such as eruption of the affected tooth, surrounding tissue, preferential location of the cyst, the incidence of the maxillary bones and adherence to the root surface. In the occurrence of LPC, the erupted tooth is generally involved and the mucosa of the area commonly has a normal appearance. In its relationship with the root, the cyst is adjacent rather than adhered as in other types (11). However, in the case reported here, the cyst was found adhered to the tooth root.
Besides being asymptomatic, the non-inflammatory lesion is located between the roots of two teeth in most cases (usually premolars and canines) (5). The mandible is generally the most affect area, particularly in the premolar region, followed by the area between the lateral incisor and canine $(3,5)$. In the case reported here, however, the lesion was in the premolar region of the maxilla.

Periapical radiography reveals LPC as a juxtaposed area on the lateral surface of two contiguous teeth between the alveolar crest and root apices, rarely more than one $\mathrm{cm}$ in diameter $(1,9)$. The lesion appears round or oval, with a well-circumscribed inter-radicular radiolucent area and usually with a sclerotic margin, as in the present case (12). Radiographic examination is not sufficient for diagnosis, since other lesions that develop between roots of adjacent teeth, such as keratocysts, may have an identical appearance (10).

Surgical enucleation is the most often employed treatment for this type of lesion, with no tendency toward recurrence, as observed in the present case. This procedure should be performed with due caution so as not to damage the adjacent root structure and to reduce the risk of recurrence (4).

As in the case reported here, the histological appearance of LPC is characterized by a cavity supported by fibrous connective tissue, which has a hyalinized zone, and lined by a thin non-proliferative layer of epithelium $(1,4)$. Focal epithelial thickening or plaques composed of clear cells (rich in glycogen) may also be found $(3,11)$. Remnants of dental lamina are often found near the cyst wall, while inflammation is rarely observed (1). All these aspects were seen in the present case.

\section{Conclusions}

The case reported here reveals that the extremely rare botryoid variant of lateral periodontal cyst exhibits multilocular presentation and excessive growth. The botryoid cyst reached the point of causing facial asymmetry, which led the patient in question to seek treatment. Its association with a tooth initially confounded the determination of LPC due to its similarity to other cystic lesions and diagnosis was only confirmed through histological examination. Excisional biopsy was the treatment for this case and no sign of recurrence was observed over the nine-month followup period.

\footnotetext{
References 1. Nart J, Gagari E, Kahn MA, Griffin TJ. Use of guided tissue regeneration in the treatment of a lateral periodontal cyst with a 7-month reentry. J Periodontol 2007;78:1360-4.

2. Méndez P, Junquera L, Gallego L, Baladrón J. Botryoid odontogenic cyst: clinical and pathological analysis in relation to recurrence. Med Oral Patol Oral Cir Bucal 2007; 12:E594-8.

3. Senande MFF, Figueiredo R, Aytés LB, Gay Escoda C. Lateral periodontal cysts: a retrospective study of 11 cases. Med Oral Patol Oral Cir Bucal 2007;13:313-7.

4. Lima AAS, Machado MAN, Braga AMC, Souza MH. Cisto periodontal lateral: etiologia, diagnóstico e significado clínico. Revisão e relato de caso. Rev Clín Pesq Odontol 2005; 1:55-8.

5. Saygun I, Ozdemir A, Safali M. Lateral periodontal cyst. Turk J Med Sci $2001 ; 31: 375-8$.
} 
6. Pereira AM, Segundo AVL, Falcão MFL, Andrade ESS, Silva UD, Silva JJ. Cisto periodontal lateral em localização pouco usual. Odontol Clín-Cient 2006;5:75-81.

7. Albuquerque Júnior RLC, Pereira JC, Fakouri R, Lessa Filho LS. Cisto odontogênico botrióide: relato de um caso. Rev Bras Patol Oral 2005;4:12-6.

8. Huang YL, Lin LM, Lin CC, Yan YH. Calcifying odontogenic cyst presenting as a lateral periodontal cyst - a case report. Chinese Dent J 1990;9:42-6.

9. Kerezoudis NP, Donta-Bakoianni C, Siskos G. The lateral periodontal cyst: aetiology, clinical significance and diagnosis. Endod Dent Traumatol 2000;16:144-50.

10. Neville BW, Damm DD, Allen CM, Bouquot JE. Patologia oral \& maxilofacial. $2^{a}$ ed. Rio de Janeiro: Guanabara Koogan; 2004.

11. Domingues AM, Gil JN. Cistos odontogênicos intra-ósseos: diagnóstico e tratamento. São Paulo: Santos; 2007.

12. Mendes RA, Van der Wall I. An unusual clinicoradiographic presentation of a lateral periodontal cyst - report of two cases. Med Oral Patol Oral Cir Bucal 2006;1 1:185-7. 